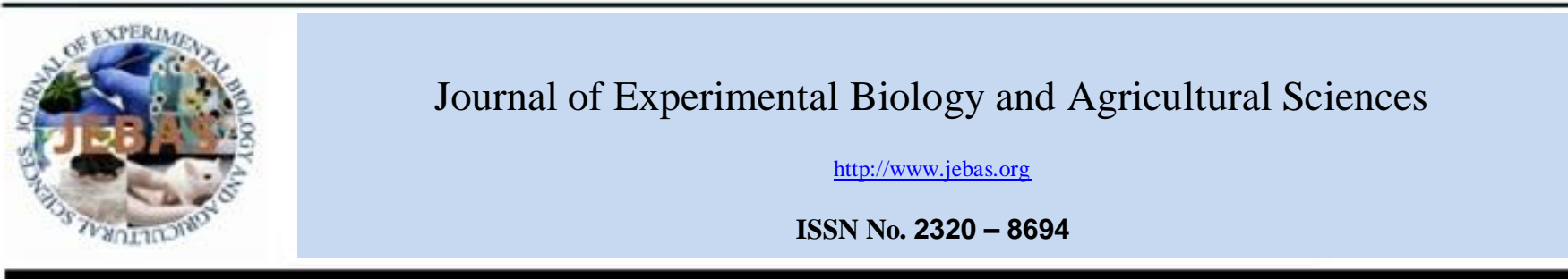

\title{
UTILIZATION OF WHEAT STRAW FOR THE PRODUCTION OF ASPARAGINASE IN SOLID-STATE FERMENTATION
}

\section{Chanakya Pallem}

Ganesh Scientific Research Foundation (GSRF), Kirti Nagar, New Delhi-110015, India

Received - November 14, 2018; Revision - December 30, 2018; Accepted - January 11, 2019

Available Online - February 5, 2019

DOI: http://dx.doi.org/10.18006/2019.7(1).51.56

\section{KEYWORDS \\ Asparaginase \\ Fusarium oxysporum \\ Optimization \\ Wheat straw \\ Solid-state fermentation}

\begin{abstract}
Asparaginase is one of the most widely used industrial enzymes of therapeutic significance; in present study an attempt had been undertaken to synthesize asparaginase from an inexpensive and abundantly available wheat straw agro-waste by solid-state fermentation of Fusarium oxysporum NCIM 1008. The essential fermentation variables were optimized to enhance the microbial growth and enzyme activity. The maximal asparaginase yield (21.54 U/gds) was reported with $60 \%(\mathrm{v} / \mathrm{w})$ initial moisture content, $\mathrm{pH}$ 6.0 , supplemented with $0.75 \%$ L-asparagine and incubated at $30{ }^{\circ} \mathrm{C}$ for $96 \mathrm{~h}$. Present investigation clearly indicated that under suitable conditions, asparaginase enzyme can be produced commercially by using the agro-waste, wheat straw on large-scale in an economically feasible way.
\end{abstract}

* Corresponding author

E-mail: pallemchanakya@yahoo.com (Chanakya Pallem)

Peer review under responsibility of Journal of Experimental Biology and Agricultural Sciences.

Production and Hosting by Horizon Publisher India [HPI] (http://www.horizonpublisherindia.in/).

All rights reserved.
All the article published by Journal of Experimental Biology and Agricultural Sciences is licensed under a Creative Commons Attribution-NonCommercial 4.0 International License Based on a work at www.jebas.org.

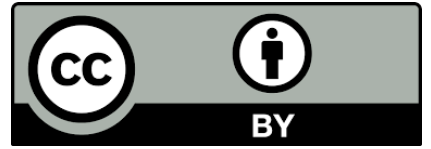




\section{Introduction}

Over the past few decades, cost-effective agro-waste materials are being utilised in several bioprocess technologies for the production of many value-added products of industrial importance. Some of the most commonly used agro-waste are oil cakes, fruit and vegetable peel, bagasse etc. (Pandey et al., 1999; Ellaiah et al., 2002). Transforming these nutritional rich waste materials into useful bio-products by fermentation process not only minimises the process cost but also reduces the risk of environmental threats (Pandey et al., 1999).

Wheat straw is one of the predominant agro-waste materials with an immense potential due to its wide availability and low-cost. It is an abundant by-product from harvesting of wheat crop in many nations like India. Further, wheat straw has been successfully, used as a raw material for pulp and paper production (Nasser et al., 2015), as a substrate for renewable energy sources such as biogas and bio-ethanol (Ferreira et al., 2014; Huang et al., 2017; Tomás-Pejó et al., 2017), enzymes production (Gao et al., 2008; Ahmed et al, 2018; Shahryari et al., 2018) and also in the commercial cultivation of mushrooms. Even though wheat straw is nutritionally rich, but high lignocelluloses and other nutritional elements are preventing it as a primary feed source for ruminants.

L-asparaginase (L-asparagine amidohydrolase, EC 3.5.1.1) is a vital enzyme, involved in the hydrolysis of L-asparagine. It has gained eminent significance due to its potent therapeutic applications especially in treating various forms of leukaemia (Adamson \& Fabro, 1968; Umesh et al., 2007; Anjana et at., 2018). The activity of asparaginase is broadly present in plants, animals, and micro organisms. Microbial production of this enzyme has attracted more attention because of its cost-effective and eco-friendly process. Normally, submerged fermentation (SmF) process has been widely used for the production of asparaginase (Basha et al., 2009; Amena et al., 2010; Gurunathan \& Sahadevan, 2012). Although, SmF process is a very well established, but it has few drawbacks such as huge volume of waste water generation and difficulties in effluent treatment process (Datar, 1986). To overcome the above disadvantages, solid-state fermentation (SSF) has come into existence as an alternate economical process for the synthesis of various metabolites by utilizing the agro-waste materials (Pandey et al., 1999). SSF has been employed for production of various microbial metabolites (Sircar et at., 1998; Sarada \& Sridhar, 1998; Corona et at., 2005; Sandhya et al., 2005; Rojan et al., 2006). As per the documented literature, a wide range of microbial genera such as filamentous fungi (Mishra, 2006; Baskar \& Renganathan, 2011), bacteria (Heinemann \& Howard, 1969; Abdel-Fattah \& Olama, 2002; Kumar et al., 2010; Seyedeh et al., 2011), yeast (Kil et al., 1995; Ramakrishnan \& Joseph,
1996) and actinomycetes (Basha et al., 2009) have been reported for the production of asparaginase.

The aim of this study was to synthesize asparaginase enzyme from an inexpensive substrate, wheat straw and optimizing the process parameters that enhance the enzyme productivity. Till today, there is no published data are available related to the production of asparaginase using wheat straw under solid-state fermentation by Fusarium oxysporum NCIM 1008.

\section{Materials and Methods}

\subsection{Materials}

Wheat straw was obtained from the nearby agricultural fields of National Capital Region (NCR) area, India. Before use it was cleaned and dried in hot air oven at $60{ }^{\circ} \mathrm{C}$ for $24 \mathrm{~h}$, milled and sieved to $1 \mathrm{~mm}$ particle size. All the chemicals used in this research work were of analytical grade and purchased from Sigma-Aldrich, Bangalore, India.

\subsection{Microorganism}

The microbial strain, F. oxysporum NCIM 1008 was received from National Centre for Industrial Microorganisms (NCIM), Pune. Obtained culture was maintained on potato dextrose agar (PDA) medium slants at $28{ }^{\circ} \mathrm{C}$ for seven days. The slants were stored at $4{ }^{\circ} \mathrm{C}$ and were sub-cultured monthly. Under aseptic conditions, $F$. oxysporum conidial suspension was prepared from a freshly raised seven day old culture by suspending in $10 \mathrm{ml}$ of $0.85 \%$ sterile saline solution. This suspension was used as inoculum for subsequent fermentation experiments.

\subsection{Solid-state fermentation of wheat straw}

Wheat straw $(5 \mathrm{~g}$ ) was dispensed into $250 \mathrm{ml}$ of cotton-plugged erlenmeyer flasks, moistened with $5 \mathrm{ml}$ of salt solution containing glucose $(0.6 \%), \mathrm{KH}_{2} \mathrm{PO}_{4}(0.1 \%), \mathrm{MgSO}_{4} .7 \mathrm{H}_{2} \mathrm{O}(0.05 \%)$ and $\mathrm{KCl}$ $(0.05 \%)$ and autoclaved. Aseptically, the flasks were inoculated with $2 \mathrm{ml}$ of the fungal conidial suspension. The contents in the flasks were mixed uniformly and incubated in a static incubator at $28{ }^{\circ} \mathrm{C}$ for about one week (fermentation time) respectively.

\subsection{Enzyme extraction and assay}

Crude enzyme was extracted as reported by Ghosh et al. (2013). L-asparaginase activity was determined by measuring the amount of ammonia released by Nesslerization according to the method (Wriston \& Yellin, 1973). One unit (U) of Lasparaginase is defined as the amount of enzyme required to liberate one $\mu \mathrm{mol}$ of ammonia under optimal assay conditions, and expressed as activity of asparaginase (U) obtained per grams of dry substrate (U/gds). 


\subsection{Optimization studies}

Various crucial process parameters in solid-state fermentation such as fermentation time, initial moisture content, initial $\mathrm{pH}$, incubation temperature and supplementation of nutritional (both carbon and nitrogen) sources were optimised using single-parameter optimization methodology. Samples were drawn continuously at $12 \mathrm{~h}$ time interval and the enzyme assay was carried out to calculate the enzyme activity. All the experiments and assays were run in triplicate and the mean values are noted for better results.

\section{Results and discussion}

The selection of a promising substrate in solid-state fermentation is an essential factor because the production cost of any bioprocess mainly depends upon the cost and availability of the substrate utilized. In this study, wheat straw has been selected as a potential substrate for the production of asparaginase based on its chemical and nutritional composition, cost and availability (Binod et al., 2010; Martin et al., 2012). Further optimization was carried out using the wheat straw as substrate to elevate the enzyme activity.

\subsection{Effect of fermentation time}

To estimate the fermentation time, SSF was performed with various fermentation time schedules ranging from 12-168 h. For this, wheat straw (5g), inoculated with $2 \mathrm{ml}$ of fungal conidial suspension with initial moisture content of $60 \%(\mathrm{v} / \mathrm{w})$ and incubated at $28{ }^{\circ} \mathrm{C}$. Samples were removed for every $12 \mathrm{~h}$ and enzyme activity was analysed. The enzyme productivity has shown growth relatedness with the incubation time progressed and maximum enzyme activity (7.04 U/gds) was observed after 96 h (Figure 1). Normally, microbial cell growth and enzyme production were dependent on the duration of fermentation. After $96 \mathrm{~h}$, the enzyme productivity started to decrease gradually. The reason for this is that the microorganism might have reached a stage, from which it could no longer balance its steady growth with the available nutrient resources. The results obtained are in accordance with the data published for the production of Lasparaginase using coconut oil cake (Ghosh et al., 2013).

\subsection{Initial moisture content}

In SSF, optimum level of initial moisture content is very important parameter and directly affects the maximum substrate utilization, microbial growth and enzyme productivity. Various moisture contents varying from 40-80\% (v/w) were taken for SSF. Maximum enzyme activity $(9.72$ $\mathrm{U} / \mathrm{gds}$ ) was noticed at $60 \%$ moisture content (Figure 2) after $96 \mathrm{~h}$ of fermentation. Decrease in enzyme activity was noticed at low and high level of moisture content. With increasing moisture content, there is a reduction in porosity and increases the chances of contamination (Lonsane et al., 1985).

\subsection{Effect of initial pH of the substrate}

In these experiments, the $\mathrm{pH}$ of the moistening solution used was set from 4-10 using $1 \mathrm{~N} \mathrm{HCl}$ or $\mathrm{NaOH}$. From the results (Figure 3), maximum asparaginase productivity was noted with $\mathrm{pH} 6.0$ (12.18 U/gds). In view of the data reported, agro-industrial materials used in SSF possess excellent buffering capacity (Pandey \& Radhakrishnan, 1992). $\mathrm{pH}$ of the medium strongly affects the growth and activity of the micro-organisms. Generally, fungal strains are noted for their best performance in the range of 3.5-6 and low $\mathrm{pH}$ avoids contamination by other microbes. Further increase in $\mathrm{pH}$ resulted in the reduction of enzyme activity which might be due to the denaturation or inactivation of the microbial strain at extreme acidic and basic $\mathrm{pH}$ values.

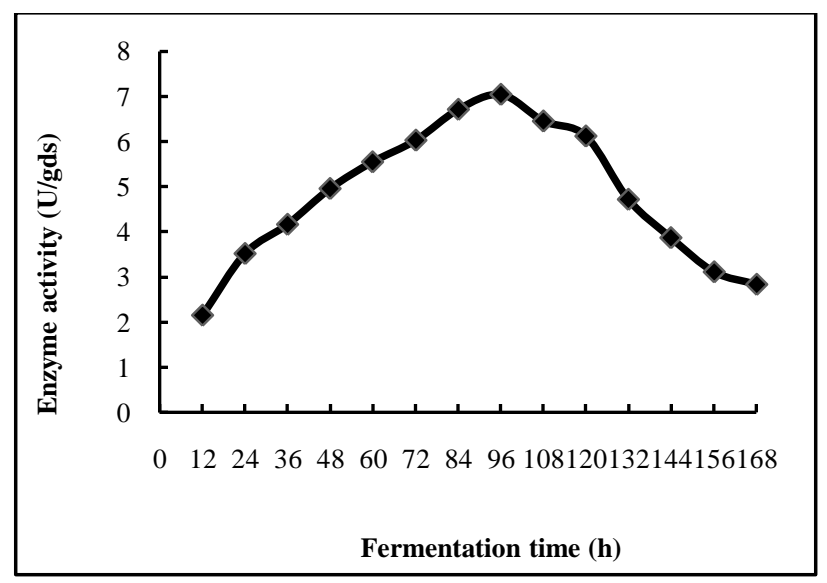

Figure 1 Effect of fermentation time on asparaginase synthesis

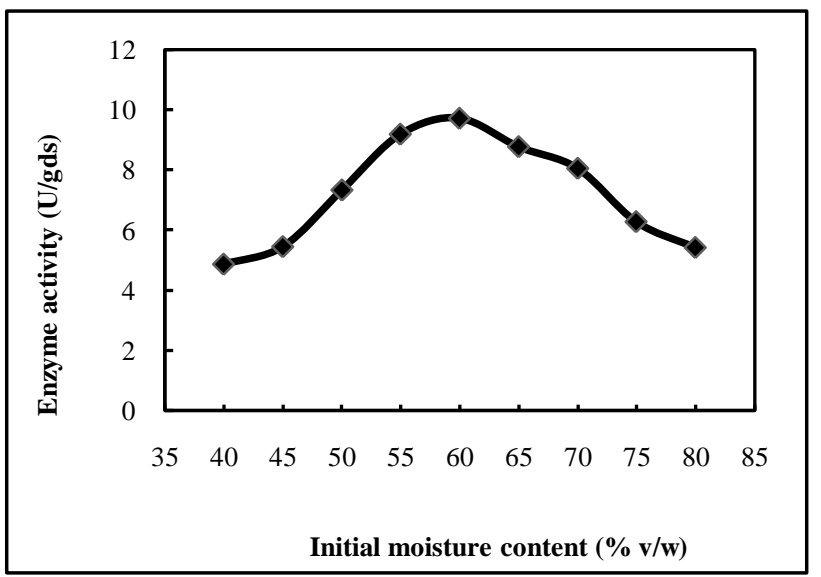

Figure 2 Effect of initial moisture content on asparaginase synthesis 


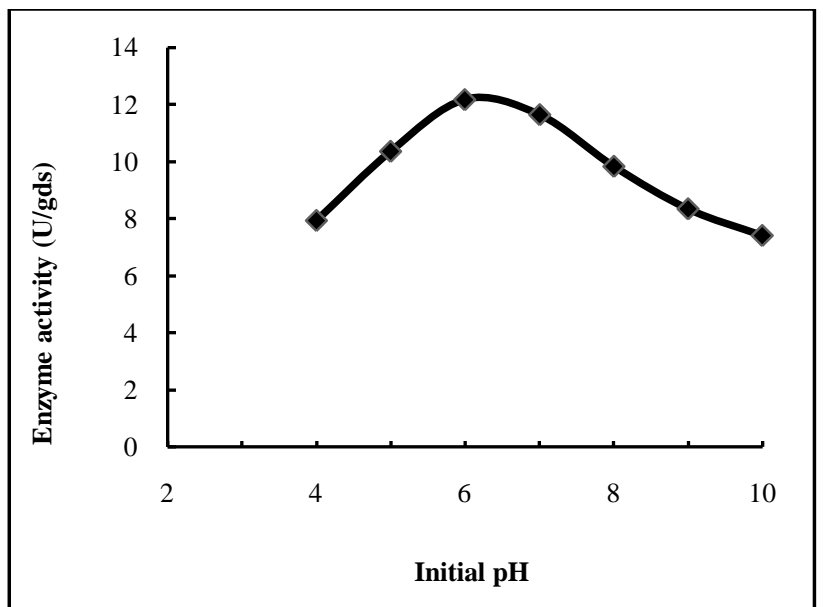

Figure 3 Effect of Initial $\mathrm{pH}$ on asparaginase synthesis

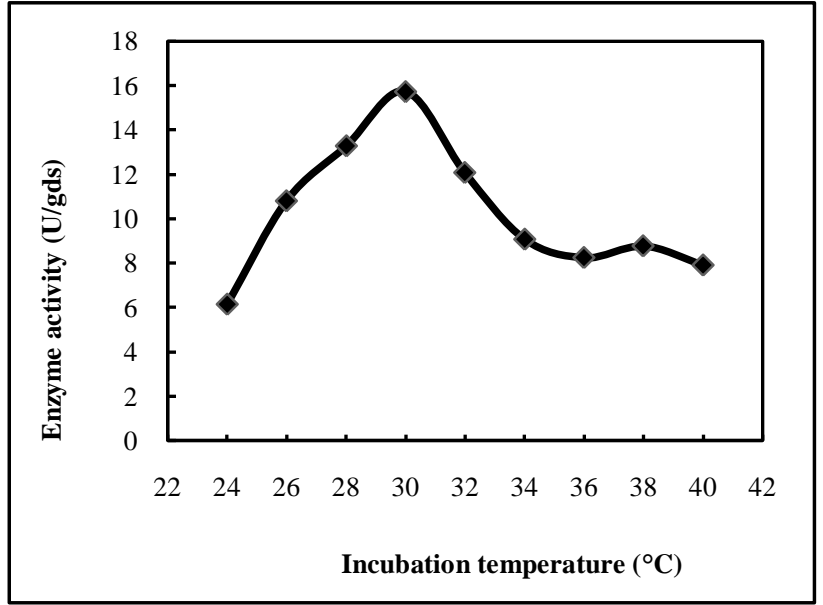

Figure 4 Effect of incubation temperature on asparaginase synthesis

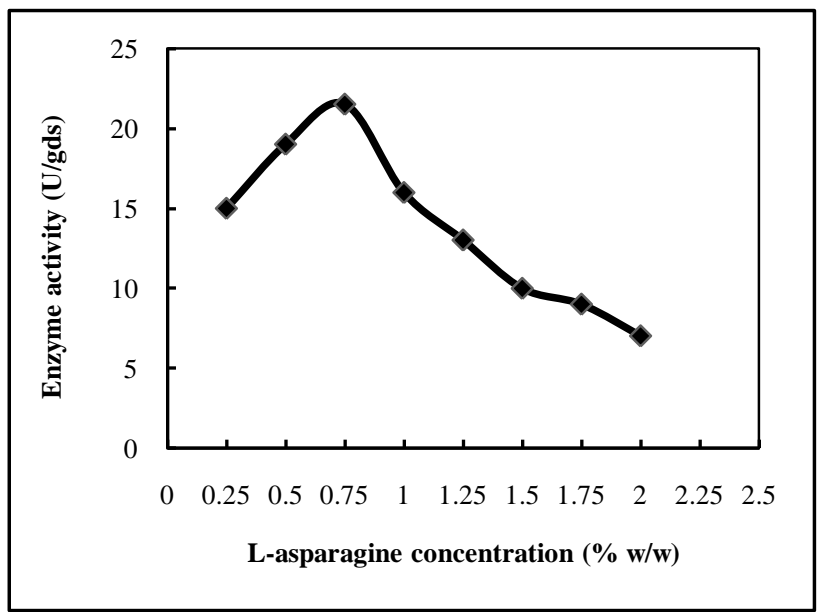

Figure 5 Effect of L-asparagine concentration on asparaginase synthesis

\subsection{Effect of temperature}

SSF was carried out at different incubation temperatures varying from 26 to $40{ }^{\circ} \mathrm{C}$. The initial moisture content was maintained at $60 \%$ (v/w), inoculated with $2 \mathrm{ml}$ of the fungal suspension. After $96 \mathrm{~h}$, the samples were extracted and examined for enzyme activity. The fungal strain has shown better growth and enzyme productivity at $30{ }^{\circ} \mathrm{C}$ and it was $15.94 \mathrm{U} / \mathrm{gds}$ (Figure 4). In biological processes, the temperature is useful in determining the effects of protein denaturation, enzyme inhibition, promotion or suppression of a particular metabolite, cell viability and death. During SSF, there is a general rise in the temperature of the fermenting mass due to respiration (Pandey \& Radhakrishnan, 1992)

\subsection{Effect of additional nutritional sources}

Various available carbon sources (fructose, galactose, glucose, maltose and soluble starch) and nitrogen sources (ammonium sulphate, ammonium chloride, yeast extract, peptone, urea, malt extract, beef extract and L-asparagine) were incorporated to the production medium at $1 \%$, but only L-asparagine has shown a positive impact on enzyme activity and microbial growth to great extent. Since addition of L-asparagine stimulated asparaginase synthesis, attempts were made to estimate the optimum concentration of L-asparagine for maximum enzyme synthesis by the fungal culture. SSF was performed with different doses of L-asparagine varying from 0.25 to $3 \%$ (w/w). Enzyme productivity increased with L-asparagine concentration in a relative manner. The maximum enzyme activity (21.54 U/gds) was noticed with $0.75 \%$ L-asparagine dose (Figure 5). With further increase in L-asparagine concentration, there was a gradual decrease in the enzyme yield which might be due to the inhibitory effect of L-asparagine at higher doses on the microbial growth and enzyme productivity.

After optimizing all the essential influential process parameters, final SSF experiment was carried out by incorporating all the standardized optimized parameters and samples were analysed for enzyme productivity. The maximum enzyme yield of $21.54 \pm 0.04$ U/gds was reported.

\section{Conclusion}

Solid-state fermentation was favourably employed to optimize process variables for maximal asparaginase productivity. Under the observed conditions, asparaginase activity of $21.54 \mathrm{U} / \mathrm{gds}$ was reported. The results of this investigation have demonstrated that effective utilization of wheat straw might reduce the production cost of therapeutically important asparaginase enzyme.

\section{Acknowledgments}

I would like to thank Ganesh Scientific Research Foundation (GSRF), New Delhi for providing necessary infrastructure and other facilities to carry out my work. 


\section{Conflict of interest}

The corresponding author declares that there is no conflict of interest.

\section{References}

Abdel-Fattah YR, Olama ZA (2002) L-asparaginase production by Pseudomonas aeruginosa in solid-state culture: Evaluation and optimization of culture conditions using factorial designs. Process Biochemistry 38: 115-122.

Adamson RH, Fabro S (1968) Antitumor activity and other biologic properties of L-asparaginase. Cancer Chemotherapy Reports 52: 617-626.

Ahmed AAQ, Babalola OO, McKay T (2018) Cellulase- and Xylanase-Producing Bacterial Isolates with the Ability to Saccharify Wheat Straw and Their Potential Use in the Production of Pharmaceuticals and Chemicals from Lignocellulosic Materials. Waste Biomass Valorization 9: 765-775.

Amena S, Visalakshi N, Prabhakar M, Dayanand A, Lingappa K (2010) Production, purification and characterization of Lasparaginase from Streptomyces gulbargensis. Brazillian Journal of Microbiology 41: 173-178.

Anjana KV, Bhumi S, Dushyant D, Haresh ZP, Haren G, Rakesh R, Bharti PD (2018) Characterization of L-asparaginase from marine-derived Aspergillus niger AKV-MKBU, its antiproliferative activity and bench scale production using industrial waste. International Journal of Biological Macromolecules 108: 41-46.

Basha NS, Rekha R, Komala M, Ruby S (2009) Production of extracellular anti-leukaemic enzyme L-asparaginase from marine Actinomycetes by solid state and submerged fermentation: Purification and Characterization. Tropical Journal of Pharmaceutical Research 8: 353-360.

Baskar G, Renganathan S (2011) Design of experiments and artificial neural network linked genetic algorithm for modeling and optimization of L-asparaginase production by Aspergillus terreus MTCC 1782. Biotechnology and Bioprocess Engineering 16: 50-58.

Binod P, Sindhu R, Singhania RR, Surender Vikram, Lalitha Devi, Satya Nagalakshmi, Noble Kurien, Sukumaran RK, Pandey A (2010) Bioethanol production from rice straw. Bioresource Technology 101: 4767-4774.

Corona A, Sa'ez D, Agosin E (2005) Effect of water activity on gibberellic acid production by Gibberella fujikuroi under solid-state fermentation conditions. Process Biochemistry 40: 2655-2658.
Datar R (1986) Economics of primary separation steps in relation to fermentation and genetic engineering. Process Biochemistry 21: 19-26.

Ellaiah P, Adinarayana K, Bhavani Y, Padmaja P, Srinivasulu B (2002) Optimization of process parameters for glucoamylase production and solid state fermentation by a newly isolated Aspergillus species. Process Biochemistry 38: 615-620.

Ferreira L, Nilsen P, Fdz-Polanco F, Pérez-Elvira S (2014) Biomethane potential of wheat straw: influence of particle size, water impregnation and thermal hydrolysis. Chemical Engineering Journal 242: 254-259.

Gao J, Weng H, Zhu D, Yuan M, Guan F, Xi Y (2008) Production and characterization of cellulolytic enzymes from the thermoacidophilic fungal Aspergillus terreus M11 under solid-state cultivation of corn stover. Bioresource Technology 99: 7623-7629.

Ghosh S, Murthy S, Govindasamy S, Chandrasekaran M (2013) Optimization of L-asparaginase production by Serratia marcescens (NCIM 2919) under solid state fermentation cake. Sustainable Chemical Process $1: 1-8$.

Gurunathan B, Sahadevan R (2012) Optimization of culture conditions and bench-scale production of $\mathrm{L}$-asparaginase by submerged fermentation of Aspergillus terreus MTCC 1782. Journal of Microbiology and Biotechnology 22 : 923-929.

Heinemann B, Howard AJ (1969) Production of tumor-inhibitory L-asparaginase by submerged growth of Serratia marcescens. Applied Microbiology 18: 550-554.

Huang C, Lai C, Wu X, Huang Y, He J, Huang C, Li X, Yon Q (2017) An integrated process to produce bio-ethanol and xylooligosaccharides rich in xylobiose and xylotriose from high ash content waste wheat straw. Bioresource Technology 241: 228-235.

Kil JO, Kim GN, Park I (1995) Extraction of extracellular Lasparaginase from Candida utilis. Bioscience Biotechnology and Biochemistry 59: 749-750.

Kumar S, Dasu VV, Pakshirajan K (2010) Localization and production of novel L-asparaginase from Pectobacterium carotovorum MTCC 1428. Process Biochemistry 45: 223-229.

Lonsane BK, Ghildyal NP, Budiatman S, Ramakrishna SV (1985) Engineering aspects of solid-state fermentation. Enzyme Microbial Technology 7: 258-265.

Martin JGP, Porto E, Correa CB, Alencar SM, Gloria EM, Cabral ISR, Aquino LM (2012) Antimicrobial potential and chemical composition of agro-industrial wastes. Journal of Natural Products 5:27-36. 
Mishra A (2006) Production of L-asparaginase, an anticancer agent, from Aspergillus niger using agricultural waste in solid state fermentation. Applied Biochemistry and Biotechnology 135: 3-42.

Nasser RA, Hiziroglu S, Abdel-Aal MA, Al-Mefarrej HA, Shetta ND, Aref IM (2015) Measurement of some properties of pulp and paper made from date palm midribs and wheat straw by soda-AQ pulping process. Measurement 62:179-186.

Pandey A, Radhakrishnan S (1992) Packed bed coloum bioreactor for enzyme production. Enzyme and Microbial Technology 14: 486-488.

Pandey A, Selvakumar P, Soccol CR, Nigam P (1999) Solid state fermentation for the production of industrial enzymes. Current Science 77: 149-162.

Ramakrishnan MS, Joseph R (1996) Characterization of an extracellular asparaginase of Rhodosporidium toruloides CBS14 exhibiting unique physicochemical properties. Canadian Journal of Microbiology 42: 316-325.

Rojan P, John K, Nampoothiri M, Pandey A (2006) Solid-state fermentation for L-lactic acid production from agro wastes using Lactobacillus delbrueckii. Process Biochemistry 41: 759-763.

Sandhya C, Sumantha A, Szakacs G, Pandey A (2005) Comparative evaluation of neutral protease production by Aspergillus oryzae in submerged and solid-state fermentation. Process Biochemistry 40: 2689-2694.
Sarada I, Sridhar P (1998) Nutritional improvement for Cephamycin C fermentation using a superior stain of Streptomyces clavuligerus. Process Biochemistry 33:317-322.

Seyedeh LDK, Iran A, Vida M (2011) Production of Lasparaginase from Escherichia coli ATCC 11303: Optimization by response surface methodology. Food and Bioproducts Processing 89: 315-321.

Shahryari Z, Fazaelipoor MH, Setoodeh P, Ramkumar BN, Taherzadeh MJ, Ghasemi Y (2018) Utilization of wheat straw for fungal phytase production. International Journal of Recycling Organic Waste in Agriculture 7: 345-355.

Sircar A, Sridhar P, Das PK (1998) Optimization of solid state medium for the production of clavulanic acid by Streptomyces clavuligerus. Process Biochemistry 33: 283-289.

Tomás-Pejó E, Fermoso J, Herrador E, Hernando H, Jiménez-Sánchez S, Ballesteros M, González-Fernández C, Serrano DP (2017) Valorization of steam-exploded wheat straw through a biorefinery approach: bioethanol and bio-oil co-production. Fuel 199: 403-412.

Umesh K, Shamsher S, Wamik A (2007) Pharmacological and clinical evaluation of L-asparaginase in the treatment of Leukemia. Critical Reviews in Oncology/Hematology 61: 208-221.

Wriston JC, Yellin TO (1973) L-asparaginase: a review. Advances in Enzymology and Related Areas of Molecular Biology 39: 185-248. 